\title{
Influence of Metal Salts on Lignocellulose Degradation by Mesophilic Fungi under Submerged Conditions
}

\author{
Tanvi* and Sneh Goyal \\ Department of Microbiology, CCS Haryana Agricultural University, Hisar-125004, \\ Haryana, India \\ *Corresponding author
}

\section{A B S T R A C T}

\begin{tabular}{|l|}
\hline K e y w o r d s \\
Cellulose, Lignin, Fungi, \\
Lignocellulolytic, \\
Submerged
\end{tabular}

\section{Introduction}

Lignocellulose is the major component of plant biomass. It is also known as photomass as it includes around half of the plant matter produced by photosynthesis and represents the most abundant renewable organic resource in soil. The increasing worldwide expansion of agro-industrial activity has generated a lot of lignocellulosic residue from various sources such as forest (waste wood, sawdust), agriculture (sugarcane bagasse, sugar cane, corn husks and banana), municipal waste (paper) and various industrial wastes (Sánchez, 2009) which are principally made up of cellulose, hemicellulose and lignin. In
Lignocellulose is the most abundant plant residue which is composed of cellulose, hemicelluloses and lignin. Some filamentous fungi have developed the ability to use ulose, hemicelluloses and lignin as energy source. The objective of this research was to (Manganese sulfate, Ferrous sulfate and Zinc sulfate) on the lignocellulolytic activity of four fungal isolates HST11, HST14, HST15 and HST16 conditions. An experimental design was applied with repetitions consisting of six treatments each for three metal salts (three treatments for cellulolytic activity and three for ligninolytic activity). The lignocellulolytic activities of all the isolates decreased with addition of these metal salts in comparison to medium without addition of any salt. At $0.003 \mathrm{~g} / \mathrm{L} \mathrm{MnSO}_{4}, 0.0025 \mathrm{~g} / \mathrm{L} \mathrm{FeSO}_{4}$ and $0.0015 \mathrm{~g} / \mathrm{L} \mathrm{ZnSO}_{4}$ maximum cellulolytic activity was observed. Maximum ligninolytic activities were observed at $0.25 \mathrm{~g} / \mathrm{L}$ concentration of these metal salts.

plants, lignin forms a strong hydrophobic meshwork which protects the plant cells from microbial and enzymatic attack complicating the degradation of lignocellulosic biomass (Zhao et al., 2012). Much research has been conducted in order to reuse the biomass in order to produce biofuels (ethanol), enzymes, compost and other metabolites. Many microorganisms that produce lignocellulolytic enzymes have been studied for many decades. Both bacteria and fungi are known to produce lignocellulolytic enzymes using complex lignocellulosic substrates. The organisms which are predominantly responsible for the degradation of lignocellulosic biomass are fungi, especially the basidiomycetes 
(Rabinovich et al., 2004) as fungal enzymes are generally complete comprising all the lignocellulosic activities.

Cellulose, the major fraction of lignocellulosic biomass, can be hydrolyzed to glucose by cellulase enzymes. However, the key obstacle for transitioning lignocellulosic feedstock is the presence of lignin in them, which retards the artificial cellulases during the cellulose hydrolysis (Zhao et al., 2012). Fungi degrade lignin by secreting a consortium of extracellular enzymes cooperatively known as "ligninases". Ligninases can be classified as either phenol oxidases (laccase) or heme peroxidases [lignin peroxidase (LiP), manganese peroxidase $(\mathrm{MnP})$, versatile peroxidase (VP)] (Martinez et al., 2005).

The expression system of oxidative enzymes of white-rot fungi is highly regulated by the nutrients that the fungi are exposed to, so that if a fungus can grow on a medium supplemented with lignin, it may produce extracellular enzyme(s) that can promote degradation/ modification of lignin or ligninderived components. Secondly, if such enzyme activity would be supplemented to a lignocellulosic substrate undergoing cellulolytic hydrolysis, then the added enzyme activity might boost the conversion of the cellulose (Sitarz et al., 2013). Therefore it is evident that the appropriate physicochemical conditions play an important role in the enzyme production by microorganisms. The aim of this study was to analyze the effect of three metal salts $\left(\mathrm{MnSO}_{4}, \mathrm{FeSO}_{4}\right.$ and $\left.\mathrm{ZnSO}_{4}\right)$ on the lignocellulolytic activity of four fungal isolates.

\section{Materials and Methods}

A laboratory experiment was conducted in the Soil Microbiology Laboratory of Department of Microbiology, Chaudhary Charan Singh Haryana Agricultural University, Hisar,
Haryana, India. Four morphologically distinct lignocellulolytic fungi HST11, HST14, HST15 and HST16, already isolated earlier from soil samples collected from different ecological sites of CCS Haryana Agricultural University, Hisar and surrounding area by serial dilution plate method using Potato Dextrose Agar (PDA) media $(300 \mathrm{ml}$ potato extract, $20.0 \mathrm{~g}$ dextrose and $20.0 \mathrm{~g}$ agar) in $1 \mathrm{~L}$ of deionised water and examined for their ability to produce lignocellulolytic enzymes were acquired from Soil Microbiology lab, Department of Microbiology, CCS HAU, Hisar. These fungal isolates were further subjected to varying concentrations of different metal salts to understand their effect on release of lignocellulolytic enzymes from them. The fungal isolates were maintained by periodic transfer on PDA slants. These isolates were stored at $4{ }^{\circ} \mathrm{C}$ for further use.

\section{Quantitative estimation of lignocellulolytic activity}

Fungal isolates were inoculated into $25 \mathrm{ml}$ malt extract broth (malt extract $30 \mathrm{~g}$ and mycological peptone $5 \mathrm{~g}$ in $1 \mathrm{~L}$ deionised water) in $50 \mathrm{ml}$ capacity flask. All the inoculated flasks were incubated at $28 \pm 2{ }^{\circ} \mathrm{C}$ for 7 days. The growth suspension was centrifuged at 4,000 rpm for 10 minutes in the REMI Research Centrifuge to separate the supernatant from the hyphal growth and other debris. Five enzyme activities namely, laccase (lac), lignin peroxidase (LiP), manganese peroxidase $(\mathrm{MnP})$, exoglucanases (filter paper degrading activity) and endoglucanases (carboxymethyl cellulase activity) were measured. Laccase (Shandilya and Munjal, 1983), lignin peroxidase (Tien and Kirk, 1988) and manganese peroxidase (Paszczynski et. al. 1988) production were measured with alkali lignin as substrate. CMCase and FPase production were measured by the method described by Ghose (1987). Reducing sugars produced due to enzymatic actions were 
determined by 3,5-dinitrosalicylic acid (DNS) method (Miller, 1959). One International Unit (IU) of enzyme was defined as the amount of enzyme required to produce $1 \mu \mathrm{mol}$ of reducing sugars per minute under the assay conditions.

Optimization of metal salts for efficient lignocellulolytic enzyme production

Lignocellulolytic enzyme production was determined in malt extract broth at $\mathrm{pH} 6$ and $28 \pm 2^{\circ} \mathrm{C}$ temperature. To understand the effect of metal salts on enzymes produced, the amendments of different concentrations of three metal salts $\mathrm{MnSO}_{4}, \mathrm{FeSO}_{4}$ and $\mathrm{ZnSO}_{4}$, were made to find out optimum conditions for efficient enzyme production (Table 1). All the inoculated flasks were incubated at $28 \pm 2^{\circ} \mathrm{C}$ for 7 days. The amount of enzymes released in the broths was estimated after incubation in comparison with uninoculated control.

\section{Results and Discussion}

In this study four lignocellulolytic fungi HST11, HST14, HST15 and HST16, already isolated earlier from soil samples collected from different ecological sites of CCS Haryana Agricultural University, Hisar and surrounding area and examined for their ability to produce lignocellulolytic enzymes were acquired from Soil Microbiology lab, Department of Microbiology, CCS HAU, Hisar and further subjected to varying concentrations of different metal salts to understand their effect on release of lignocellulolytic enzymes from them.

\section{Optimization of metal salts for efficient lignocellulolytic enzyme production}

The four fungal isolates listed above were further subjected to varying concentrations of different metal ions for efficient lignocellulolytic enzyme production. Lignocellulolytic fungi require trace amount of essential elements like $\mathrm{Cd}, \mathrm{Mn}$ or $\mathrm{Zn}$ for their growth but presence of these metals in excess may become toxic for fungi however, the sensitivity towards metal salts may vary among different species (Baldrian, 2003).

The influence of three metal salts $\mathrm{MnSO}_{4}$, $\mathrm{FeSO}_{4}$ and $\mathrm{ZnSO}_{4}$ as inorganic inductors on lignocellulolytic enzyme production was studied in malt extract broth. Interestingly, HST11 and HST15 were not at all showing any cellulolytic activity. The cellulolytic activity of HST14 and HST16 and ligninolytic activities of all the isolates decreased with addition of these metal salts to the medium in comparison to medium without addition of these salts (Table 2).

Table.1 Different metal salt concentrations for lignocellulolytic enzyme activities

\begin{tabular}{|l|c|c|}
\hline \multirow{2}{*}{ Metal ions } & \multicolumn{2}{|c|}{ Concentration (g/L) } \\
\cline { 2 - 3 } & For cellulase activity & For ligninases activity \\
\hline $\mathrm{MnSO}_{4}$ & $0.003,0.006,0.009$ & $0.25,0.51 .0$ \\
\hline $\mathrm{FeSO}_{4}$ & $0.0025,0.005,0.0075$ & $0.25,0.51 .0$ \\
\hline $\mathrm{ZnSO}_{4}$ & $0.0015,0.003,0.0045$ & $0.25,0.51 .0$ \\
\hline
\end{tabular}


Table. 2 Cellulolytic and ligninolytic enzyme activities of selected fungal isolates without addition of metal salts

\begin{tabular}{|l|l|l|l|l|l|}
\hline \multirow{2}{*}{ Fungal isolate } & Cellulolytic activities (IU/ml) & Ligninolytic activities (IU/ml) \\
& FPase & CMCase & Lac & LiP & MnP \\
\hline HST11 & - & - & 12.00 & 20.00 & 3.48 \\
\hline HST14 & 0.015 & 0.010 & 8.75 & 15.00 & 2.75 \\
\hline HST15 & - & - & 16.00 & 21.00 & 2.60 \\
\hline HST16 & 0.016 & 0.012 & 20.00 & 48.00 & 2.50 \\
\hline C.D. at 5\% & 0.001 & 0.002 & 1.802 & 1.484 & 1.873 \\
\hline
\end{tabular}

Table.3 Cellulolytic and ligninolytic enzyme activities of selected fungal isolates at different $\mathrm{MnSO}_{4}$ concentrations

\begin{tabular}{|c|c|c|c|c|c|}
\hline \multirow[t]{2}{*}{ Fungal isolate } & \multicolumn{2}{|c|}{ Cellulolytic activities (IU/ml) } & \multicolumn{3}{|c|}{ Ligninolytic activities (IU/ml) } \\
\hline & FPase & CMCase & Lac & LiP & MnP \\
\hline & \multicolumn{2}{|c|}{$0.009 \mathrm{~g} / \mathrm{L}$} & \multicolumn{3}{|c|}{$1.00 \mathrm{~g} / \mathrm{L}$} \\
\hline HST11 & - & - & 1 & 1 & 1 \\
\hline HST14 & 0.000 & 0.001 & 3 & 1 & 1 \\
\hline HST15 & - & - & 2 & 2 & 1 \\
\hline HST16 & 0.001 & 0.000 & 5 & 2 & 2 \\
\hline \multirow[t]{2}{*}{ C.D. at 5\% } & 0.001 & 0.001 & 1.696 & 0.526 & 0.526 \\
\hline & \multicolumn{2}{|c|}{$0.006 \mathrm{~g} / \mathrm{L}$} & \multicolumn{3}{|c|}{$0.50 \mathrm{~g} / \mathrm{L}$} \\
\hline HST11 & - & - & 6 & 8 & 1 \\
\hline HST14 & 0.010 & 0.005 & 4 & 7 & 1.6 \\
\hline HST15 & - & - & 5 & 9 & 2 \\
\hline HST16 & 0.009 & 0.005 & 8 & 6 & 2 \\
\hline \multirow[t]{2}{*}{ C.D. at 5\% } & 0.003 & 0.002 & 1.052 & 1.331 & 0.526 \\
\hline & \multicolumn{2}{|c|}{$0.003 \mathrm{~g} / \mathrm{L}$} & \multicolumn{3}{|c|}{$0.25 \mathrm{~g} / \mathrm{L}$} \\
\hline HST11 & - & - & 9 & 14 & 1.5 \\
\hline HST14 & 0.012 & 0.007 & 6 & 9 & 1.9 \\
\hline HST15 & - & - & 11 & 10 & 2.4 \\
\hline HST16 & 0.013 & 0.009 & 16 & 10 & 2.5 \\
\hline C.D. at 5\% & 0.003 & 0.002 & 2.232 & 0.674 & 0.686 \\
\hline
\end{tabular}


Table.4 Cellulolytic and ligninolytic enzyme activities of selected fungal isolates at different $\mathrm{FeSO}_{4}$ concentrations

\begin{tabular}{|l|l|l|l|l|l|}
\hline & Cellulolytic activities (IU/ml) & \multicolumn{4}{l|}{ Ligninolytic activities (IU/ml) } \\
& FPase & CMCase & Lac & LiP & MnP \\
\hline & $\mathbf{0 . 0 0 7 5} \mathbf{g} / \mathbf{L}$ & & $\mathbf{1 . 0 0 g} / \mathbf{L}$ & & \\
\hline HST11 & - & - & 0 & 0.3 & 0.1 \\
\hline HST14 & 0.001 & 0.000 & 0 & 0.6 & 0.5 \\
\hline HST15 & - & - & 0 & 0.1 & 0 \\
\hline HST16 & 0.003 & 0.006 & 1 & 7 & 1.6 \\
\hline C.D. at 5\% & 0.002 & 0.001 & 0.686 & 0.970 & 1.025 \\
\hline & $\mathbf{0 . 0 0 5} \mathbf{g} / \mathbf{L}$ & & $\mathbf{0 . 5 0 g} / \mathbf{L}$ & & \\
\hline HST11 & - & - & 2 & 0.9 & 1.25 \\
\hline HST14 & 0.008 & 0.006 & 1.7 & 0.9 & 0.5 \\
\hline HST15 & - & - & 1 & 0.5 & 1 \\
\hline HST16 & 0.010 & 0.006 & 3 & 10 & 2.3 \\
\hline C.D. at 5\% & 0.002 & 0.003 & 1.065 & 0.526 & 0.600 \\
\hline & $\mathbf{0 . 0 0 2 5} \mathbf{g} / \mathbf{L}$ & & $\mathbf{0 . 2 5 g} / \mathbf{L}$ & & \\
\hline HST11 & - & - & 2.5 & 1 & 0.5 \\
\hline HST14 & 0.010 & 0.007 & 3.2 & 1.2 & 1 \\
\hline HST15 & - & - & 3 & 0.9 & 1 \\
\hline HST16 & 0.012 & 0.010 & 4 & 10 & 3 \\
\hline C.D. at 5\% & 0.003 & 0.001 & 1.351 & 1.331 & 1.118 \\
\hline
\end{tabular}

Table.5 Cellulolytic and ligninolytic enzyme activities of selected fungal isolates at different $\mathrm{ZnSO}_{4}$ concentrations

\begin{tabular}{|c|c|c|c|c|c|}
\hline \multirow[t]{2}{*}{ Fungal isolate } & \multicolumn{2}{|c|}{ Cellulolytic activities (IU/ml) } & \multicolumn{3}{|c|}{ Ligninolytic activities (IU/ml) } \\
\hline & FPase & CMCase & Lac & LiP & MnP \\
\hline & \multicolumn{2}{|c|}{$0.0045 \mathrm{~g} / \mathrm{L}$} & \multicolumn{3}{|c|}{$1.00 \mathrm{~g} / \mathrm{L}$} \\
\hline HST11 & - & - & 1 & 0 & 1 \\
\hline HST14 & 0 & 0 & 0.4 & 0 & 1 \\
\hline HST15 & - & - & 0.9 & 0 & 0 \\
\hline HST16 & 0 & 0 & 2.2 & 0 & 0.3 \\
\hline \multirow{2}{*}{ C.D. at 5\% } & 0.001 & 0.001 & 0.780 & 0 & 1.078 \\
\hline & \multicolumn{2}{|c|}{$0.0030 \mathrm{~g} / \mathrm{L}$} & \multicolumn{3}{|c|}{$0.50 \mathrm{~g} / \mathrm{L}$} \\
\hline HST11 & - & - & 2 & 1 & 1 \\
\hline HST14 & 0.009 & 0.006 & 0.8 & 0 & 2 \\
\hline HST15 & - & - & 1 & 1 & 0 \\
\hline HST16 & 0.008 & 0.010 & 4 & 1.2 & 0.5 \\
\hline \multirow[t]{2}{*}{ C.D. at $5 \%$} & 0.003 & 0.003 & 1.450 & 1.222 & 1.164 \\
\hline & \multicolumn{2}{|c|}{$0.0015 \mathrm{~g} / \mathrm{L}$} & \multicolumn{3}{|c|}{$0.25 \mathrm{~g} / \mathrm{L}$} \\
\hline HST11 & - & - & 7 & 2 & 2 \\
\hline HST14 & 0.009 & 0.007 & 1 & 3 & 2.5 \\
\hline HST15 & - & - & 4 & 1 & 0 \\
\hline HST16 & 0.010 & 0.010 & 9 & 3 & 1 \\
\hline C.D. at 5\% & 0.023 & 0.001 & 1.460 & 1.392 & 1.025 \\
\hline
\end{tabular}


For cellulase activities, three different concentrations of $\mathrm{MnSO}_{4}(0.003,0.006$ and $0.009 \mathrm{~g} / \mathrm{L})$ were added in the broth. FPase and CMCase activities increased from 0.001 $\mathrm{IU} / \mathrm{ml}$ and $0.000 \mathrm{IU} / \mathrm{ml}$ respectively at 0.009 $\mathrm{g} / \mathrm{L}$ to $0.013 \mathrm{IU} / \mathrm{ml}$ and $0.009 \mathrm{IU} / \mathrm{ml}$ respectively at $0.003 \mathrm{~g} / \mathrm{L}$ concentration for HST16. For ligninolytic activities three different concentrations $(0.25,0.50$ and 1.0 $\mathrm{g} / \mathrm{L})$ were added to the broth. Maximum Lac activity was $16 \mathrm{IU} / \mathrm{ml}$ for HST16 at $0.25 \mathrm{~g} / \mathrm{L}$. Similarly, maximum LiP activity was 14 $\mathrm{IU} / \mathrm{ml}$ for HST11 at $0.25 \mathrm{~g} / \mathrm{L}$ and maximum MnP activity was $2.45 \mathrm{IU} / \mathrm{ml}$ for HST15 at $0.25 \mathrm{~g} / \mathrm{L}$ concentration. All these activities were significantly different from other isolates (Table 3). On addition of $\mathrm{FeSO}_{4}$ in the broth, the FPase and CMCase activities were $0.003 \mathrm{IU} / \mathrm{ml}$ and $0.006 \mathrm{IU} / \mathrm{ml}$ respectively, at $0.0075 \mathrm{~g} / \mathrm{L}$ and increased to $0.012 \mathrm{IU} / \mathrm{ml}$ and $0.016 \mathrm{IU} / \mathrm{ml}$ respectively, at $0.0025 \mathrm{~g} / \mathrm{L}$ for HST16. For ligninolytic activities, three different concentrations $(0.25$, 0.50 and $1.0 \mathrm{~g} / \mathrm{L}$ ) were added to the $\mathrm{ME}$ broth. Maximum Lac, LiP and MnP activities were $4 \mathrm{IU} / \mathrm{ml}, 10 \mathrm{IU} / \mathrm{ml}$ and $3 \mathrm{IU} / \mathrm{ml}$ respectively for $\mathrm{HST} 16$ at $0.25 \mathrm{~g} / \mathrm{L}$ concentration which were significantly different from other isolates (Table 4). Addition of $\mathrm{ZnSO}_{4}$ in the broth resulted in maximum cellulase activities for HST16 which increased from $0.000 \mathrm{IU} / \mathrm{ml}$ at 0.0045 $\mathrm{g} / \mathrm{L}$ to $0.010 \mathrm{IU} / \mathrm{ml}$ at $0.0015 \mathrm{~g} / \mathrm{L}$. Similarly, for ligninolytic activities, three different concentrations $(0.25,0.50$ and $1.0 \mathrm{~g} / \mathrm{L})$ were added to the MEA broth. Maximum Lac activity was observed for HST16 (9 IU/ml), LiP activity of $3 \mathrm{IU} / \mathrm{ml}$ for HST14 and HST16 and maximum MnP activity $042.5 \mathrm{IU} / \mathrm{ml}$ for HST14 (Table 5). Similarly, Chmelova et al., 2011 also observed that the introduction of metal salts/ions to the growth medium decreased the cellulolytic and ligninolytic activities of fungus $C$. subvermispora. in another study Levin et al., 2008, observed that the presence of heavy metals negatively affect the growth of lignocellulolytic fungi which is sometimes accompanied with a prolonged lag phase. They observed that cellulase of $P$. chrysosporium in liquid media got inhibited due to the presence of 50-150 ppm cadmium, copper, lead, manganese, nickel and cobalt. Also, mercury, iron and copper inhibited the activity of $\beta$-glucosidase from Trametes gibbosa, but copper had no influence on the production of cellulolytic enzymes by $T$. trogii.

\section{Acknowledgement}

We greatly acknowledged the Department of Microbiology, College of Basic Sciences and Humanities, CCSHAU Hisar, Haryana, India for the help and financial support during execution of the experiments.

\section{References}

Baldrian, P. 2003. Interactions of heavy metals with white-rot fungi. Enzyme and Microbial Technology. 32: 78-91.

Chmelová, D., Ondrejovič, V, Ondáš, V., Šturdík, E. 2011. Influence of cultivation conditions on production of lignocellulolytic enzymes by Ceriporiopsis subvermispora. Biologia. 66(5): 748-754.

Ghose, T.K. 1987. Measurement of cellulase activities. Pure and Applied Chemistry. 59: 257-268.

Levin, L., Herrmann, C. and Papinutti, V.L. 2008. Optimization of lignocellulolytic enzyme production by the white-rot fungus Trametes trogii in solid-state fermentation using response surface methodology. Biochemical Engineering Journal. 39: 207-214.

Martinez, A.T., Speranza, M., Ruiz-Duenas, F.J., Ferreira, P., Camarero, S., Guillen, F., Martinez, M.J., Gutierrez, A. and Rio, J.C. 2005. Biodegradation of lignocellulosics: microbial, chemical, 
and enzymatic aspects of the fungal attack of lignin. International Microbiology 8: 195-204.

Miller, G.L. 1959. Use of dinitrosalicylic acid reagent for determination of reducing sugar. Analytical Chemistry. 31: 426428.

Paszczynski, A., Huynhv, B., Crawford, R. 1988. Enzymatic activities of an extracellular, manganese-dependent peroxidase from Phanerochaete chrysosporium. FEMS Microbiology Letters 29: 37-41.

Rabinovich, M.L., Bolobova, A.V. and Vasil'chenko, L.G. 2004. Fungal decomposition of natural aromatic structures and xenobiotics: a review. Applied Biochemistry and Microbiology. 40(1): 1-17.

Sanchez, C. 2009. Lignocellulosic residues: Biodegradation and bioconversion by fungi. Biotechnology Advances. 27: 185-194.

Shandilya, J.R., Munjal, R.L. 1983. Some experiments with casing layer. Tai-wanYang-ku: Taiw Mush 7(1): 32-38.

Sitarz, A. K., Mikkelsen, J. D., Højrup, P. \& Meyer, A. S. 2013. Identification of a laccase from Ganoderma lucidum CBS 229.93 having potential for enhancing cellulase catalyzed lignocellulose degradation. Enzyme and Microbial Technology. 53: 378- 385.

Tien, M., Kirk, T.K. 1988. Lignin peroxidase of Phanerochaete chrysosporium. Methods in Enzymology 161: 238-249.

Zhao, X., Zhang, L. and Liu, D. 2012. Biomass recalcitrance. Part I: the chemical compositions and physical structures affecting the enzymatic hydrolysis of lignocellulose. Biofuels, Bioproducts \& Biorefining: 6: 465-482.

\section{How to cite this article:}

Tanvi and Sneh Goyal. 2018. Influence of Metal Salts on Lignocellulose Degradation by Mesophilic Fungi under Submerged Conditions. Int.J.Curr.Microbiol.App.Sci. 7(11): 14011407. doi: https://doi.org/10.20546/ijcmas.2018.711.162 